\title{
Práticas e Representações Fúnebres: preparações para a morte na Campinas oitocentista
}

\section{Funeral Representations and Practices: Preparations to Death in Campinas of the Nineteenth Century}

\author{
João Paulo Berto ${ }^{1}$
}

joaopberto@yahoo.com.br

Resumo

$\mathrm{O}$ artigo trata de aspectos do campo fúnebre de Campinas, São Paulo, no século XIX, enfatizando as atividades à margem da liturgia oficial, entre elas procissões, ofícios e rezas, uso de mortalhas e ritos de enterramentos que auxiliavam a população em geral a inculcar os preceitos religiosos acerca dos ritos fúnebres, sobretudo com o apoio das irmandades que forneciam aos seus irmãos aportes próprios no pré e pós-morte. Com base em fontes distintas como jornais e testamentos, observou-se que no período as liturgias institucionais da Igreja Católica, dadas por meio de catecismos, manuais e livros sobre a prática do bem viver e morrer, circularam e foram ressignificadas em processos culturais dinâmicos que imprimiram na sociedade campineira características essenciais no modo de se tratar a morte e seus mortos.

Palavras-chave: Campinas (SP), século XIX; Ritos e Cerimônias Fúnebres; Irmandades.

\begin{abstract}
This article treats of the aspects of the funeral field of Campinas, São Paulo, in the nineteenth century, emphasizing activities on the sidelines of the official liturgy, like processions, religious services and prayers, use of shrouds and burial rites that helped the population to inculcate religious precepts about the funeral rites, especially with the support of the brotherhoods supplied before and after death. Based on different sources such as newspapers and wills, we were observed in the period that the institutional liturgies of the Catholic Church, given through catechisms, manuals and books about the practice of well living and dying were circulated and re-signified in dynamic cultural processes that marked in the Campinas society essential characteristics in the way of treat the death and yours deads.
\end{abstract}

Keywords: Campinas (SP), 19th Century; Funeral Rites and Ceremonies; Brotherhoods.

1 Doutorando em História da Arte pelo Instituto de Filosofia e Ciências Humanas da Universidade Estadual de Campinas (IFCH/Unicamp). 
Artigos

\section{Introdução ${ }^{2}$}

A morte, certamente, é um dos aspectos mais importantes da liturgia e da piedade popular, uma vez que se mostra como um elemento incerto, levando o homem a vivenciá-la e celebrá-la das mais diferentes formas. Porém, a ideia tridentina de que a vida era uma constante preparação para a morte teve um papel importante, efetivada por meio da produção de imagens e pela manipulação de símbolos em um conjunto cerimonial ou festivo em que os atos litúrgicos ganhavam novas cores, sons, gestos e práticas, integrando de forma mais eficaz a vivência da população. A partir de um núcleo comum de ordenações litúrgicas, cada grupo ou comunidade desenvolvia atitudes e expressões peculiares, na forma de práticas e representações, capazes de assumir culturalmente o valor de elementos fixos de organização das sociedades (GONZÁLES, 2007, p. 13).

Trazido pela influência ibérica, este cenário foi comum a inúmeras cidades do Brasil, sendo marcantes as transformações ocorridas ao longo dos oitocentos. Assim, busca-se apresentar um pequeno panorama das práticas de sociabilidades desenvolvidas em torno da morte na cidade paulista de Campinas, importante centro político, econômico e cultural desde o século XIX. A cidade, inicialmente o povoado de Campinas do Mato Grosso, ligado à Freguesia de Jundiaí, foi constituída no início da segunda metade do século XVIII e, antes mesmo de ter sua capela, elemento marcante para a dinâmica urbana, teve aprovado um campo santo como modo de prover as almas dos habitantes. Assim, desde o Cemitério Bento setecentista, este tipo de preocupação foi quase uma constante na história local, criando diversos aparatos culturais fúnebres que iam das celebrações quaresmais ao uso de mortalhas, toques de sinos e sufrágios cheios de pompa.

\section{A Semana Santa campineira como forma de educação para a morte}

A colonização portuguesa auxiliou na difusão da Semana Santa, intensificada no século XVIII com a mineração e realizada com toda a pompa barroca da devoção aos santos, à Virgem Dolorosa e ao Cristo sofredor dos martírios. Nesta linha, tradições foram desenvolvidas, como procissões, romarias, encomendação de almas, orações de invocação e perdão, sempre pautadas na vivência de temores e crenças da morte salvadora e na busca por proteção, sobretudo no fim da vida do fiel. Para Ana Guiomar Rêgo Souza, as semanas santas no Brasil colonial e imperial acabaram por ter seus focos dirigidos para as imagens do padecimento de Cristo, mas não significando somente uma exaltação da morte e da dor. Para ela,

(...) o devoto queria evidentemente se salvar, mas no âmbito das exigências temporais, ou seja: através de uma leve mortificação da carne, participação irregular nos diversos sacramentos da Igreja e, sobretudo, recorrendo ao valor protetor e salvífico da Paixão de Cristo (SOUZA, 2007, p. 87).

A Semana Santa, a cada ano, buscava reavivar o significado da Paixão, Morte e Ressurreição de Cristo na vida do fiel, construído por meio de atos e símbolos. Pelo discurso eclesiástico, Cristo teria, sozinho, carregado as dores e enfermidades do povo (Is 53, 3-12) e morrido pelo pecado da humanidade, redimindo-a; porém, venceu a morte com sua ressurreição e abriu as portas da salvação para a humanidade.

Neste tempo litúrgico, as personagens bíblicas desfilavam nas procissões, capelas passos eram abertas, estruturas efêmeras montadas nas igrejas, sempre acompanhadas de grande esplendor por orquestras e coros que executavam peças de artistas locais ou regionais compostas para este fim. Para tanto, as celebrações e os atos seguiam uma ordem cronológica da narração da Paixão, minuciosamente organizados pelas Igrejas e capelas, amparadas pelas irmandades, confrarias e ordens terceiras, em especial as do Santíssimo Sacramento, da Misericórdia e do Senhor Bom Jesus dos Passos.

Em Campinas, as semanas santas aconteciam com preparativos e iniciativas das irmandades locais, conforme pode ser observado pelos jornais campineiros, permeadas pelos jogos das hierarquias e privilégios sociais. Dada a escassez de fontes para o início dos oitocentos, os relatos da segunda metade do século XIX,

$2 \mathrm{O}$ artigo retoma algumas discussões apresentadas na dissertação de mestrado defendida pelo autor junto ao IFCH/Unicamp, sob orientação da Profa. Dra. Eliane Moura da Silva e com apoio financeiro da Fundação de Amparo à Pesquisa do Estado de São Paulo (Fapesp). 
sobretudo entre 1860 e 1880, são capazes de apontar o grande volume de fiéis vindos para as celebrações, não só do aglomerado urbano, mas também das áreas rurais e de localidades vizinhas. Segundo Xavier,

A celebração da Semana Santa era capaz de concentrar em uma mesma ocasião, os mais diversos segmentos sociais, fossem eles senhores ou seus escravos (vindos do campo, das localidades vizinhas, etc.) (...) O catolicismo, através de ritos como estes, definitivamente, movimentava a vida da localidade e a Igreja, ciente deste poder mobilizador, funcionava através do pároco e de seu sermão, como uma importante e eficaz força repressiva na manutenção das hierarquias sociais (XAVIER, 2002, p. 91).

O primeiro ato religioso campineiro era o Setenário de Nossa Senhora das Dores, finalizado na sextafeira anterior ao Domingo de Ramos, quando os fiéis meditavam temas sobre a brevidade da vida em face das dores de Maria que, mesmo sofrendo, conseguiu alcançar as glórias celestiais. Seguia-se a ele, o Domingo de Ramos, festa que inicia “(...) os rituaes com que a egreja christã commemora o triunpho preparado em Bethfagé pelos adoradores da sublime Victima do Calvario (...)” (GAZETA DE CAMPINAS, 28 mar. 1872), estando as igrejas adornadas com palmas ${ }^{3}$, depois distribuídas entre os fiéis que as utilizavam como sacramentais.

Além do Ofício de Ramos, estava também a Procissão de Passos ou do Encontro, talvez até mais esperada que o primeiro rito solene. Realizada pela Irmandade do Senhor dos Passos da Paróquia da Conceição, e na circunscrição desta, marcava a meditação de sete passos de Jesus rumo ao Calvário dados por meio de pinturas colocadas em casas ao longo do trajeto. Todas estas atividades eram muito concorridas, em especial pelo número de confissões que eram realizadas, o que proporcionava aos pregadores atualizarem os ditames da Igreja junto ao rebanho disperso.

Após a procissão de Passos, era comum a visita dos fiéis aos passos montados nas casas para orações pessoais. Passado o Domingo de Ramos, ocorria o Ofício de Treves, na quarta-feira santa, liturgia existente desde o século XIII. O clima proporcionado por estes atos ajudavam o fiel a se sensibilizar pelo tema da morte, levando em conta que o sofrimento em vida de Jesus, bem como o de sua mãe, proporcionou as glórias celestiais.

$\mathrm{Na}$ quinta-feira, iniciavam-se os ofícios de endoenças (do latim, indulgentias), com especial relevância à cerimônia do Lava-pés com Sermão do Mandato do Amor Fraterno, relembrando o gesto de Jesus antes da última ceia com seus apóstolos, desnudamento dos Altares, procissão interna e adoração do Santíssimo exposto. Neste dia, também, antes do Lavapés, era realizado o Ofício de Trevas, com a mesma estrutura da quarta-feira, mas com textos diferentes, sobretudo derivados das lamentações do profeta Jeremias.

Na sexta-feira Santa, único dia em que não há missas no catolicismo, era realizado, pela manhã, o Ofício da Paixão com pregação e, às 15 horas, a celebração da Paixão do Senhor. À tarde, ocorria a procissão do enterro, com a presença das irmandades e grande número de fieis, sendo pregado o sermão das lágrimas. O Sermão das Lágrimas de São Pedro ou de Santa Maria Madalena referia-se a uma reflexão sobre dor e sofrimento, choro e lágrimas, além de pontos como a paciência de Cristo, a crueldade e cegueira de Judas, a cumplicidade de Pilatos, a iniquidade do processo que condenou Jesus, culminando com a crucificação e a morte de Cristo.

No Sábado Santo, havia celebrações do Ofício de Aleluia de manhã e, à tarde, a Coroação de Nossa Senhora. Para finalizar a Semana Santa, no Domingo de Páscoa, realizava-se a Procissão da Ressurreição de madrugada, saindo a imagem de Jesus Ressuscitado por um caminho e da Virgem Maria, por outro, até se encontrarem, sendo pregado o sermão do Encontro da Ressurreição. Após, era feito o Ofício da Ressurreição, com missa cantada e sermão ao evangelho.

Os atos, desde o início, aconteciam com toda a solenidade e pompa, com presença de sacerdotes externos convidados para as pregações. As descrições feitas nos jornais mostram a efervescência durante estes dias:

Se não temos ainda um templo acabado, se o recinto da velha matriz muitas vezes míngua para a multidão dos fieis, é certo, por outro lado, que a riqueza das alfaias, os custos dos ornamentos são objectos muito para vêr-se e condignos com a prosperidade e importância deste município. Neste sentido são admiráveis não somente os hábitos ecclesiásticos propriamente, mas ainda e principalmente a vestimenta de varias imagens e insígnias dos respectivos andores. A Virgem das Dores, e Senhor dos Passos, por exemplo, vestem sumptuosas túnicas e erguem-se entre esplendidos bro-

3 Segundo Leopoldo Amaral (1927, p. 341), "muitos fazendeiros do município, impulsionados pelos sentimentos religiosos, enviavam no dia de Ramos carradas de palmeiras, abundantes nas visinhas mattas para a distribuição aos fieis. (...) Havia palmas a rôdo”. 
Artigos

cados sobre charolas magníficas onde o velludo e o ouro, de par com as côres symbolicas da tristeza, realçam aquelles vultos onde se derrama em cheio a luz esplendida dos Céus (GAZETA DE CAMPINAS, 18 abr. 1870).

Os ornamentos dos templos ajudavam na meditação dos motivos piedosos, sobretudo na forma de arquiteturas efêmeras. O Calvário montado em ambas as igrejas era sempre o elemento central, iluminado a luz de velas e com palmeiras de troncos altos e esguios em grande número (AMARAL, 1927, p. 342). Conforme descrição da matriz velha, feita por Leopoldo Amaral, a celebração de quinta-feira santa apresentava um diferencial, graças ao gosto e à riqueza, estando os adornos ao encargo do armador José Pinto Nunes:

O altar-mor, de alto a baixo, resplandecia, afogado em centenares de luzes, dispostas symetricamente, alinhadas, entrelaçamentos de velludos e de seda e de flores polychromas, tudo em rigorosa observância da pompa e magnificencia recommendadas pela Egreja nesse dia (AMARAL, 1927, p. 342).

É possível observar que os temas centrais da Semana Santa são a piedade, a religião, a paixão, morte e ressurreição de Jesus. A Ressurreição é central, já que foi por meio dela que houve a remissão dos pecados e a possibilidade da salvação das almas, porém o processo que culmina com ela adquire também grande valor ao permitir extravasar nos fiéis um forte conteúdo emotivo da piedade devocional. Os manuais de Semana Santa deixavam isso bem claro, sobretudo nas explicações e nos roteiros apresentados. O modelo dos penitentes era o mais explorado, incitando os fiéis nos “(...) saudáveis rigores da austeridade (...)”, mostrando que o choro da Igreja pela morte de Jesus Cristo devia fazer com que eles chorassem “(...) sobre si mesmos” (OFFICIO, 1779, p. 775), a fim de fazê-los “(...) comprehender, que o louvor não fica bem na boca do peccador, quando os suspiros, e os gemidos de hum coração contrito, e humilhado não só a sua partilha; pois que a tristeza, conforme os sentimentos de Deos, produz para a salvação huma penitencia saudável” (OFFICIO, 1779, p. 776).

\section{Mortalhas, Ofícios, Irmandades e Testamentos: preparativos para o além}

No século XIX, os sentidos e as formas no tratamento dado à morte e aos mortos foram sendo alterados substancialmente, ao ponto de se falar de uma dessacralização das práticas culturais mortuárias. Contudo, a passagem para o além continuava devendo ser bem preparada, promovendo diversas relações de solidariedade entre vivos e mortos. O mais importante era não ser pego de surpresa, sendo mau agouro uma morte acidental ou prematura, motivo de sofrimento eterno para as almas. Por isso, "a morte devia ser de alguma forma anunciada, por meio de algum sinal, uma doença ou diretamente por forças do Além” (OFFICIO, 1779, p. 96).

As determinações dadas em vida, sobretudo na forma dos testamentos, ajudam a compreender esta necessidade de preparar o fim da existência por meio de inúmeras iniciativas. Uma fórmula corrente nos testamentos, incluindo os campineiros, era afirmar a necessidade de testar para “(...) por minha Alma no verdadeiro Caminho da Salvação (...)” (LIMA, 16 set. 1807). As estruturas que os testamentos seguem, algumas vezes apenas mudando a ordem, em grande parte devem-se aos modelos difundidos pelos manuais de boa morte, sendo destacável o presente na obra do padre Estevão de Castro, datado de 1672.

Muitas vezes, os testamentos servem como instrumentos de limpeza da consciência, já que em todos eles o testador se preocupava em relatar não somente suas últimas vontades terrenas, mas também servia de mecanismo de confissão, em que o redator apontava seus pecados, infortúnios, suas deslealdades e dívidas pendentes, tanto divinas quanto terrenas (PAGOTO, 2004, p. 32). Assim, era comum assumir filhos bastardos e apontar dívidas pendentes, sempre apelando para os vivos e para a corte celeste a possibilidade de abrandar as penas impostas à alma.

O início do testamento apresenta o valor dado ao aspecto religioso, sobretudo na preparação da alma e na necessidade de intercessores no momento derradeiro. Em 1828, o português Antônio Gonçalves Mamede apresentou um modelo típico de invocação testamentária, usual durante a primeira metade do século XIX, elemento que vai sendo simplificado aos poucos:

Jesus, Maria, José. Eu Antônio Gonçalves Mamede estando doente posto que de pé, mas receando ser esta minha moléstia a última de minha vida, estando em meu perfeito juízo e entendimento que Deos me deu fosse este testamento 
minha última vontade. Primeiramente, encomendo minha alma a Deos que me creou e pesso [ilegivel] merecimento de sua Sagrada Paixam e Morte tenha mizericordia de minha alma quando deste cárcere morte sair. Rogo a Virgem Maria Senhora Nossa seja minha advogada e protectora na prezensa de seu Unigenito filho e o Anjo da minha Guarda e Santo do meu nome implorem por mim na prezensa do mesmo Senhor e principalmente no fatal e tremento dia do Juízo. Sou verdadeiramente Christam professo a Lei de Cristo e nesta fé espero viver e morrer (MAMEDE, 20 dez. 1828).

As determinações testamentárias incidiam também no cuidado do corpo. Um elemento importante era a tradição de enterrar os mortos envoltos em tecidos, usualmente chamados de mortalhas. O campineiro José da Silva Novais, em 1830, por exemplo, pediu para que seu corpo fosse enterrado amortalhado no hábito de São Francisco, sendo que no dia do falecimento todos os sacerdotes presentes teriam que dizer missas de corpo presente por sua alma (NOVAIS, 30 abr. 1830). Lembrar dos santos de devoção ocorria não somente nos testamentos, mas também no local das sepulturas e no uso de vestimentas e hábitos religiosos um modo de assimilação do sagrado à vida do morto. Por isso, era comum o pedido do vivo para ser enterrado com vestes similares àquelas cristalizadas nas iconografias dos santos, dos anjos e da Virgem Maria. Entre os mais usuais nos testamentos campineiros, estavam São Francisco de Assis e Nossa Senhora do Carmo.

No mesmo sentido, o fiel poderia ser enterrado envolto no hábito de sua confraria ou irmandade, como foi o caso de Albano Lima. Como irmão professo da ordem do Carmo, o indivíduo passava a ter estas prerrogativas, bem como ser acompanhado pelos demais irmãos, tanto no trajeto da casa à igreja, quanto dela até o cemitério. Outro exemplo é o caso citado de José da Silva Novais, o qual, fazendo parte da Irmandade do Santíssimo Sacramento, solicitou que os irmãos acompanhassem seu corpo de sua casa até a Igreja Matriz onde seriam celebradas missas de corpo presente (NOVAIS, 30 abr. 1830); ou ainda o de Domiciana do Espírito Santo que, em 1852, nas declarações sobre seu enterro, pediu “(...) que depois de amortalhada disponha meu corpo em hum caixão e carregada por irmãos da Irmandade das Almas de quem sou Irmã, e sepultada no Cemitério" (ESPÍRITO SANTO, 1852).

Por vezes, o tipo de mortalha não era indicado, podendo ser citado apenas o desejo de que o corpo fosse "amortalhado em um hábito de pano decente", como pediu Salvador Pires Barbosa (BARBOSA, 06 dez. 1831). Além disso, o investimento também poderia ser mais simples, sendo o corpo envolto em panos nas cores preta ou branca ou a critério do testamenteiro. Vale ressaltar que todos tinham direito aos ritos fúnebres: ricos e pobres, livres e escravos. Este é o caso do ex-escravo africano Paulo Antônio de Souza que, em 1837 (SOUZA, 30 out. 1837), solicitou que seu corpo fosse envolto em uma mortalha de São Benedito, com o respectivo cordão, comprovando fazer parte da irmandade negra.

A importância das irmandades neste processo é grande, incidindo como intercessoras eficazes na morte. Os testamentos campineiros mostram esta dinâmica, elemento que justifica as filiações a estes grupos: ao mesmo tempo em que estava ligada a uma irmandade ou ordem terceira campineira, o fiel também o era a outros grupos de cidades como Itu, São Paulo, Rio de Janeiro e Santos, em um fenômeno de adesões múltiplas. Ao compor uma "teia de solidariedade", como expôs Ana Cristina Araújo (1997, p. 319), as irmandades e as ordens terceiras proporcionavam aos associados a execução dos ritos de passagem, com base em atitudes, símbolos religiosos e profanos, cortejos e cerimônias que preparavam a incorporação do morto ao além e restabeleciam a ordem social perdida com a morte. Ao estar ligado a mais de um grupo religioso, além de demonstrar o poderio econômico, o ato marcava a preocupação do indivíduo com o destino de sua alma e corpo, justamente pela vinculação e reconhecimento destes nos enterros (sepulturas) e cerimônias litúrgicas (sufrágios), aspectos inseridos nos estatutos ou compromissos como obrigações.

Em Campinas, uma das irmandades mais influentes era a do Santíssimo Sacramento da Paróquia da Conceição. Além de ter o maior número de irmãos era também a mais rica, constatado por suas alfaias e demais propriedades conservadas até os dias atuais. Além do acompanhamento dos féretros, a irmandade era a única na cidade a possuir um sino próprio, doado pelo seu reorganizador, Antonio Francisco Guimarães, na época Mordomo da associação ${ }^{4}$. Com ele, era realizado o anúncio do falecimento de um membro confrarial, acelerando a mensagem da morte a toda a comunidade.

4 Conforme Jolumá Brito (1956, p. 60-61), os dobres de sinos da matriz pelos falecidos existiam há anos, mediante o pagamento de espórtulas ao sacristão que deveria ser revertidas ao templo. Houve, inclusive, uma contenda por volta de 1836-1837 sobre o referido valor (aumentado de 160 para 320 réis), muito além do disposto nos cânones eclesiásticos. 
Artigos

Partindo de uma economia da morte, as irmandades e as ordens terceiras mantinham seus rendimentos em alta, além dos legados pios deixados pelos irmãos e outros benfeitores que objetivavam ter seus nomes colocados nas missas e ofícios litúrgicos semanais realizados pelos grupos. Entre as principais citadas nos testamentos campineiros oitocentistas, estão, em primeiro lugar, a Irmandade do Santíssimo Sacramento, seguida da Ordem Terceira do Carmo, São Miguel e Almas e a Irmandade de São Benedito. Em seu histórico sobre a Irmandade do Santíssimo Sacramento da Matriz da Conceição, ao refletir sobre os sepultamentos realizados em Campinas na segunda metade do século XIX, João Lourenço Rodrigues aponta que os mesmos

deviam ser muito solenes, dado o número de tocheiros que eram alugados, quando se tratava de pessoa abastada e grada; o consumo de cêra era enorme; uns os tomavam alugados até a Igreja e outros até o cemitério, Custava $\$ 320$ o aluguel de cada tocheiro. Para os funerais do Capitão Camilo Xavier Bueno da Silveira, rico fazendeiro, falecido em Campinas a 3 de setembro de 1871, foram alugados 260 tocheiros (RODRIGUES, 1947, p. 33).

Em Campinas, os enterros ocorriam com grande ou pouca suntuosidade e pompa. Além do acompanhamento do defunto de casa à igreja e desta ao cemitério, por parte das irmandades, havia também, em alguns casos, o uso de marchas musicais, tocadas pelas bandas da cidade, como demonstram alguns testamentos. Por outro lado, algumas pessoas buscavam realizar seus gestos finais da forma mais humilde e sem extravagâncias, como o caso do português José Leonardo Pereira que, em suas últimas vontades, declarou o desejo de ser amortalhado em um lençol velho e ser enterrado em um "lugar de mais humildade e desprezo" (PEREIRA, 05 jul. 1831). Manuel d’Oliveira Fonseca, na segunda metade da década de 1830, pediu para que o funeral fosse feito "sem pompa alguma unicamente acompanhando o meu corpo pelos Sacerdotes desta Vila; não quero acompanhamento de Muzica e mesmo officio” (FONSECA, [déc. 1830]). Este ato demonstraria um possível desapego às frivolidades mundanas na última hora, refletindo a pobreza e a humildade com que a alma deveria ter para entrar no céu.

Outros, inclusive, apegavam-se ao apoio dos outros, mesmo que fora das redes das irmandades e confrarias, como Carlota Teixeira que, em 1851, declarou que seu “(...) corpo será amortalhado e carregado em huã rede até a Igreja onde será recomendado, ed'ahi ao Semitério por algumas pessoas que queriam fazer essa esmola" (TEIXEIRA, 1851). Juntamente, este ponto refletia a condição financeira do próprio testador que sabia das exigências de uma boa morte e buscava adaptá-la a sua realidade. Um exemplo claro é o de Francisco Alvares Machado Vasconcellos que, no mesmo ano de Carlota, apenas afirmou: "Pesso que com o meu enterro se fará a só indispensável despeza para salvar a descencia” (VASCONCELLOS, 1851).

Os ritos e as práticas fúnebres pedidos nos testamentos, por mais simples que fossem, respeitavam elementos de decência e decoro. A morte, como fim do corpo, apresentava aspectos internos, de consolo aos familiares e ao próprio defunto que havia antes designado seus desejos, e externos, com os atos públicos. Todos estes, por sua vez, derivavam das liturgias da boa morte difundidas pela igreja e irmandades. Com isso, havia um núcleo comum de práticas religiosas a serem cumpridas, as quais podiam ser teatralizadas ou não. Porém, o decoro, ou seja, “o que convém”, o “decente”, o “adequado”, deveria ser sempre mantido, medidos os aspectos que mais facilitariam a entrada da alma no Paraíso.

Neste aspecto, ganham destaque os cultos e as cerimônias litúrgicas realizadas em prol das almas. Estes ofereciam a segurança, tanto aos vivos quanto aos mortos, de que o fiel poderia alcançar as bem-aventuranças com rapidez, se estivesse no Purgatório, ou gozar cada vez mais dos benefícios do céu. Nos testamentos da Campinas do século XIX, o culto às almas aparece como uma estratégia incisiva, sendo comum ao longo dos registros a importância das missas no momento da morte e nos dias, meses ou anos sucessivos.

A preocupação com o destino da alma não se extinguia com o sepultamento, elemento que se simplifica, sobretudo, após a mudança e proibição de inumações nas igrejas. O solo sagrado dos templos, junto aos santos, relíquias e demais objetos, ofereceria ao morto a proteção contra o inferno e facilidades no caminho para o céu. A mudança para os cemitérios, neste contexto, não era capaz de proporcionar o mesmo sentimento de segurança existente no sepultamento ad sanctus. Por isso, sobretudo a partir dos anos 1830, apoiado com a inauguração do Cemitério Geral em Campinas, os testadores passaram a colocar, cada vez 
mais, as disposições sobre os funerais a cargo do testamenteiro ${ }^{5}$. Contudo, no espaço antes reservado às determinações sobre onde o corpo seria depositado, se junto ao altar-mor ou a um altar do santo protetor, os testadores passaram a dispor com grande afinco sobre as missas e outras cerimônias de exéquias como aspectos definidores de uma boa morte.

É estrutura comum a estes documentos a declaração do desejo do falecido para que fossem ditas missas de corpo presente no dia do falecimento ou no dia seguinte por todos os sacerdotes que estivessem presentes na vila. As missas e demais ofícios tinham o poder simbólico de apaziguar as dores e angústias dos vivos e as dúvidas dos que estavam prestes a morrer. Neste sentido, as irmandades e as ordens terceiras uniam-se aos indivíduos que participavam de livre iniciativa nos cultos fúnebres de parentes e amigos e, até mesmo, desconhecidos, fortalecendo redes de solidariedade. Para tanto, a criação das redes de sentido era ainda maior, pois, além de preverem ofícios para eles próprios, também o faziam para familiares já falecidos, tendo ou não devoções particulares.

As quantidades de cultos solicitados variavam de acordo com o capital do testador, como João Ignácio de Deus que, em 1841, pedia que se mandasse rezar 80 missas, quarenta pela alma de seu pai e a outra metade para a de sua mãe (DEUS, 22 jan. 1841). Os destinatários destes sufrágios também eram variáveis, mantendo-se sempre pessoas da família, as almas do Purgatório, indivíduos com que o testador teve negócios em vida, escravos e, em alguns casos, pelos inimigos, perdoando-lhes no momento derradeiro como meio de se livrar dos pecados que ainda pesavam em sua consciência. Esta descrição pode ser elucidada no testamento deixado pelo provedor da Irmandade do Santíssimo Sacramento, Antônio Francisco Guimarães, o Baía:

\section{ImAgem 1 - Convite de enterro informando ao SR. Walter Adolfo Hüzmann SOBRe O falecimento de SEU IRMÃo I. Henrique Hüzmann. (Segunda metade do século XiX).}

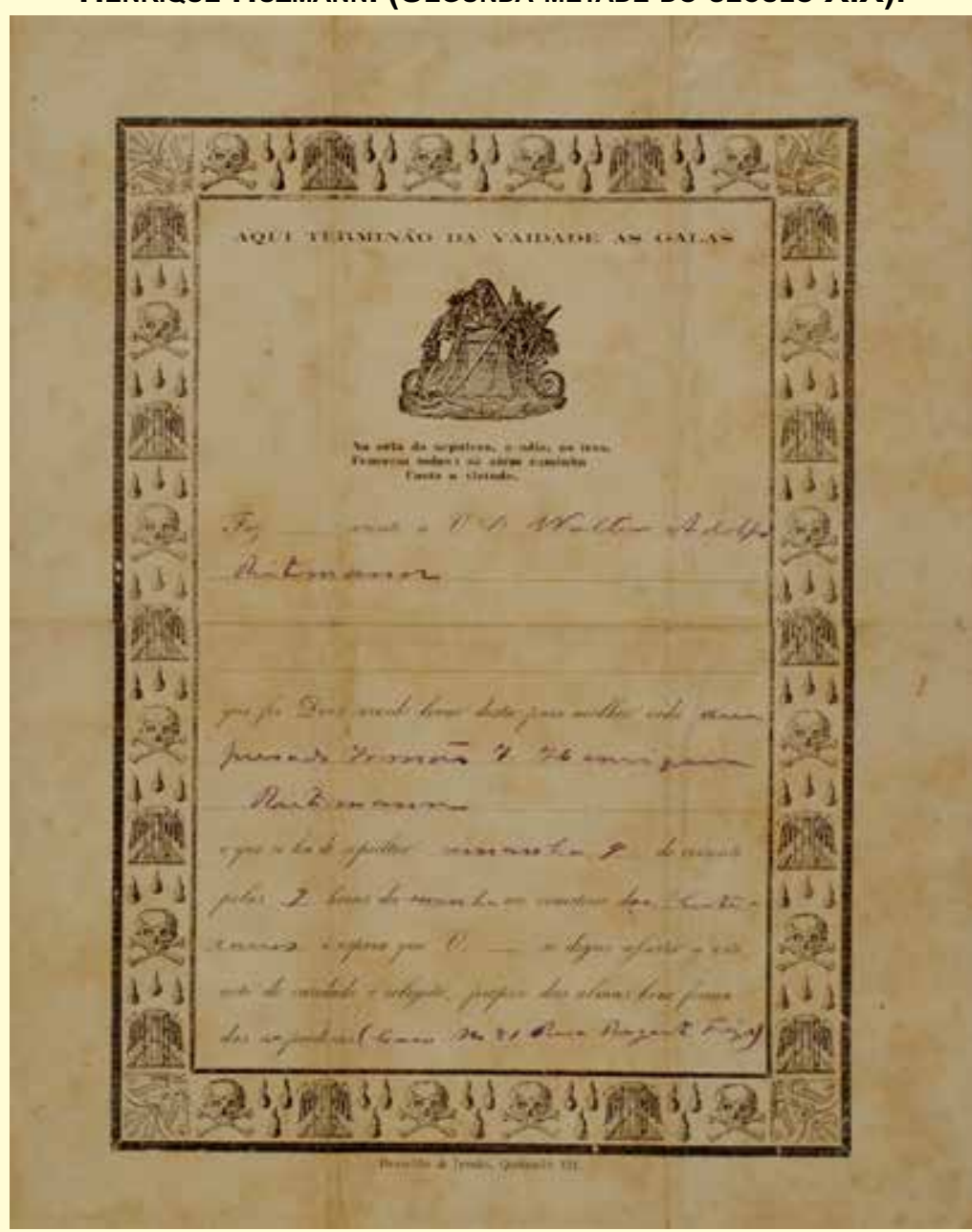

Fonte: Coleção Família Quirino dos Santos e Simões, Centro de Memória-Unicamp.
Declaro que meu testamenteiro mandará dizer honde lhe convier oito capellas de missas [uma capela equivale a cinquenta celebrações] por minha Alma; oito ditas por Almas de meus Pais; quatro ditas pelas Almas do purgatório; quatro ditas por intenção das pessoas com quem tive negócios e que por engano e ignorância minha lhe disse algum prejuízo; uma capella de missas por intenção de meus inimigos vivos e falecidos aos quais cordialmente pesso perdão para que Deos nosso Senhor pela sua infinita mizericordia se digne perdoar-me todos os meus pecados (GUIMARÃES, 04 set. 1873).

Os pedidos dos testadores, por sua vez, deveriam ser colocados em prática pelos testamenteiros que prestavam contas nos autos do processo. No que se referia aos cultos e aos enterros, esperavam-se dos amigos, familiares e conhecidos a presença nas últimas homenagens, sendo esta vista como um ato de caridade e religião, próprio das almas piedosas. Isto pode ser bem elucidado com os convites para os ritos fúnebres, tanto nos jornais campineiros oitocentistas, quanto entregues pessoalmente. Para as missas de corpo presente, criavam-se todo um aparato especializado, com profissionais que armavam a decoração fúnebre do templo e conduziam os enterros. $\mathrm{O}$ arranjo do espaço ajudava a criar o clima para a solenidade, como exposto em notícia do ofício fúnebre do Dr. Francisco Antonio de Salles, de 1871:

5 Entre os testamentos apontados, destacam-se os disponíveis nos Livros de Registro de Testamento 159 (20/10/1828 a 12/11/1834), 160 (20/02/1835 a 22/01/1841), 162 (08/01/1851 a 01/08/1852), disponíveis no acervo dos Arquivos Históricos do Centro de Memória - Unicamp. 
Artigos

Realizou-se, em a matriz da Conceição, no dia 5 do corrente ás 8horas da manhã, o officio fúnebre que os collegas e amigos do finado dr. Francisco Antonio de Salles fizeram preparar para suffragar-lhe a alma. O templo esteve pomposamente decorado sobresahindo no corpo da egreja um sumptuoso catafalco. As ceremonias correram tocantes e com aquella magestade toda do ritual christão, sendo acompanhadas pelas harmonias plangentes da nossa insegne orchestra. (GAZETA DE CAMPINAS, 07 mai. 1871).

Além das missas de corpo presente, eram também celebradas as de sétimo dia, um mês e um ano de falecimento. Estes atos poderiam ser realizados pela família ou por grupos de amigos do morto, por vezes nas duas paróquias de Campinas a fim de intensificar as preces. Estes gestos piedosos repercutiam na família do morto, a qual respondia nos jornais buscando sempre alçar a memória e importância de seu ente querido. Os termos utilizados nos textos, cheios de adjetivações, demonstram a importância das práticas, a exemplo da família de João Quirino do Nascimento que

Do fundo d'alma agradecem as immensas provas de consideração e estima tributadas á memória do seu muito e prezado e estremecido esposo, genro, irmão e cunhado (...), por todas as pessoas que concorreram ao enterro do finado e á respectiva missa do setimo dia. Não podiam os supra-assignados abafar os protestos de sincera gratidão por tão expressivas mostras de apreço ao seu chorado parente; e é por isso que os vem patentear por este modo, accumulando aqui igualmente os votos de seu reconhecimento pelas visitas que receberam. (GAZETA DE CAMPINAS, 29 jan. 1871).

Os ritos também poderiam ser realizados em prol das almas dos escravos, como quando o Sr. Antonio Carlos de Sampaio Peixoto e sua família mandaram "dizer uma missa a 6 do corrente [1872], por alma do preto Josué, que não há muito tempo deu notável prova de fidelidade e boa índole, por maneira entre nós conhecida" (GAZETA DE CAMPINAS, 06 jun. 1872). Isto demonstra que os indivíduos buscavam munir-se de diversos elementos capitais para uma boa morte, promovendo uma limpeza de consciência e demonstrando serem capazes de colocar em práticas todas as virtudes, em especial as teologais (fé, esperança e caridade).

\section{Considerações Finais}

A necessidade de se valorizar uma consciência sobre a morte e suas possíveis implicações foi fortalecida no século XIX tendo por base as paraliturgias e a ação de grupos leigos. Isso se justifica pela presença de poucos bispados, pela escassa legislação, pelo regalismo nascido do Padroado e pelas visitas pastorais com um sentido mais administrativo que apostólico, fatos que indicavam que as condições espirituais, ainda no século XIX, não eram paradigmáticas em todos os pontos (CAMPOS, 1988, p. 109-122).

As irmandades desempenharam um papel crucial, disseminando entre os membros e a comunidade a eles próxima a catequese necessária para o bom cumprimento da fé e dos ritos fúnebres cristãos. Com isso, percebe-se a coexistência de duas formas de catolicismo, em especial no campo da morte, um vinculado a uma "religião culta, dotada, já nos primórdios, de uma teologia bastante complexa," e outro a uma "tradição popular afeiçoada aos costumes e crenças pagãs, detentora de uma visão de mundo essencialmente sacral, onde a "graça" e o "infortúnio" individual ou social são interpretados como desígnios de Deus" (CAMPOS, 1988, p. 109-122).

Verifica-se, assim, o fortalecimento de uma religiosidade popular e devocional, na forma de um hábito cultural, que norteava os fiéis e dava a eles a segurança necessária, dentro de pressupostos específicos, para o seu bem-estar no final da existência terrena. Os fiéis realizavam, mesmo inconscientemente, os preparativos para a boa morte, por meio da criação de liturgias que lhes eram próprias e, portanto, plurais e condicionadas pelo contexto no qual se inseriam. Os testamentos mostram bem esta dinâmica, podendo-se elencar outros, como a participação nos ritos fúnebres de parentes ou amigos, as orações particulares, a valorização das confissões, os legados pios e a presença massiva em cerimônias festivas cuja especificidade estava na reflexão sobre a morte e sua vitória, como as realizadas durante a Semana Santa. 


\section{Fontes}

Testamentos - Fundo Tribunal de Justiça de Campinas (TJC) - Centro de Memória - Unicamp (CMU).

BARBOSA, Salvador Pires. 06 dez.1831. Livro de Registro de Testamento 159.

DEUS, João Ignácio. 22 jan. 1841. Livro de Registro de Testamento 160.

ESPÍRITO SANTO, Domiciana do. 1852. Livro de Registro de Testamento 162.

FONSECA, Manuel d'Oliveira. [déc. 1830]. Livro de Registro de Testamento 159.

GUIMARÃES, Antonio Francisco. 04 set.1873. Livro de Registro de Testamento 166.

LIMA, Albano de Almeida. 16 set.1807. Livro de Registro de Testamento 157.

MAMEDE, Antônio Gonçalves, 20 out. 1828. Livro de Registro de Testamento 159.

NOVAIS, José da Silva. 30 abr. 1830. Livro de Registro de Testamento 159.

PEREIRA, José Leonardo. 05 jul. 1831. Livro de Registro de Testamento 159.

SOUZA, Paulo Antônio de. 30 out.1837. Livro de Registro de Testamento 160.

TEIXEIRA, Carlota. 1851. Livro de Registro de Testamento 162.

VASCONCELLOS, Francisco Alvares Machado. 1851. Livro de Registro de Testamento 162.

\section{Acervo do Arquivo Edgard LeUenroth, IFCH-Unicamp.}

GAZETA DE CAMPINAS, Campinas, 18 de janeiro de 1870.

GAZETA DE CAMPINAS, Campinas, 29 de janeiro de 1871.

GAZETA DE CAMPINAS, Campinas, 07 de maio de 1871.

GAZETA DE CAMPINAS, Campinas, 28 de março de 1872.

GAZETA DE CAMPINAS, Campinas, 06 de junho de 1872.

\section{Referências}

AMARAL, Leopoldo. Campinas: recordações. São Paulo: O Estado, 1927.

ARAÚJO, Ana Cristina. A Morte em Lisboa: atitudes e representações (1700-1830). Lisboa: Notícias editorial, 1997.

BRITO, Jolumá. História da Cidade de Campinas. Campinas, 1956. Vol II.

CAMPOS, Adalgisa Arantes. Notas sobre os rituais de morte na sociedade escravista. Revista do Departamento de História da FAFICH/UFMG. Volume VI, 1988.

CARRATO, J. Ferreira. Igreja, Iluminismo e Escolas Mineiras Coloniais. São Paulo: Companhia Editora Nacional, Editora da Universidade de São Paulo, 1968.

GAETA, Maria Ap. Junqueira Veiga. A Cultura clerical e a folia popular. Revista Brasileira de História, vol. 17, n. 34. São Paulo, 1997.

GONZÁLES, Ramiro. Piedade Popular e Liturgia. São Paulo: Loyola, 2007.

OFFICIO da Semana Santa em latim, e em portuguez, com as rubricas do Missal, e Breviario Romano, e com as Orações para a Confissão, e Comunhão, tiradas da Sagrada Escritura, e no fim com o Catalogo onde se explicão as Ceremonias, e Palavras difficeis na sua intelligencia. Lisboa: na Regia Officina Typografica, 1779. 
Artigos

PAGOTO, Amanda Aparecida. Do Ámbito Sagrado da Igreja ao Cemitério Público: transformações fúnebres em São Paulo (1850-1860). São Paulo: Arquivo do Estado, Imprensa Oficial do Estado de São Paulo, 2004.

RODRIGUES, Cláudia. Os africanos e as apropriações das representações católicas sobre a morte no Rio de Janeiro colonial. Disponível em: <www.brasa.org/Documents/BRASA IX/Claudia-Rodrigues.pdf>. Acesso em: 28 fev. 2013.

RODRIGUES, João Lourenço. A vida religiosa de Campinas através do histórico da Irmandade do SS. Sacramento da Catedral: 1847-1947. Campinas: Tip. A Tribuna, 1947.

SOUZA, Ana Guiomar Rêgo. Paixões em Cena: a semana santa na cidade de Goiás (século XIX). 2007. Tese (Doutorado em História) - Instituto de Ciências Humanas, Universidade de Brasília, Brasília, 2007.

VIDE, Sebastião Monteiro da, Dom. Constituiçoes Primeiras do Arcebispado da Babia feitas, e ordenadas pelo illustrissimo e reverendíssimo senhor D. Sebastião Monteiro da Vide, $5^{\circ}$ Arcebispo do dito Arcebispado, e do Conselho de Sua Magestade. São Paulo: Typographia 2 de Dezembro de Antonio Louzada Antunes, 1853.

XAVIER, Regina Célia Lima. Tito de Camargo Andrade: religião, escravidão e liberdade na sociedade campineira oitocentista. 2002. Tese (Doutorado em História) - Instituto de Filosofia e Ciências Humanas, Universidade Estadual de Campinas, Campinas, 2002. 